\title{
Gravity anomalies, sub-surface structure and oil and gas migration in the Mamfe, Cameroon-Nigeria, sedimentary basin
}

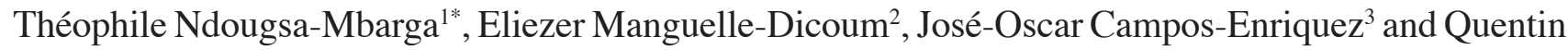 \\ Yene Atangana ${ }^{4}$ \\ ${ }^{1}$ Department of Physics, Advanced Teachers' Training College, University of Yaounde I, Yaounde, Cameroon \\ ${ }^{2}$ Department of Physics, Faculty of Science, University of Yaounde I, Yaounde, Cameroon \\ ${ }^{3}$ Instituto de Geofísica, Universidad Nacional Autónoma de México, Mexico City, Mexico \\ ${ }^{4}$ Department of Earth Science, Faculty of Science, University of Yaounde I, Yaounde, Cameroon
}

Received: October 25, 2006; accepted: June 9, 2007

\begin{abstract}
Resumen
Este estudio reporta resultados preliminares de una interpretación formal de datos existentes de un área hasta hoy desprovista de estudios geofísicos, la cuenca de Mamfe (Camerún nor-occidental/ Nigeria sur-oriental). La importancia de esta cuenca se comprende por el hecho de que está genéticamente relacionada con la depresión de Benue productora de hidrocarburos. Los mapas de anomalías gravimétricas regional y residual proporcionaron información sobre la estructura de la cuenca. Las componentes gravimétricas regional y residual se obtuvieron ajustando con el método de mínimos cuadrados una superficie polinomial de tercer grado a la anomalía de Bouguer. La anomalía residual de tercer orden revela la presencia de dos bajos gravimétricos orientados NE-SW. La anomalía occidental cubre las poblaciones de Ekok y Agbokem, y la oriental comprende a Mukonyong, Mamfe y Bachuo Akagbe. Dos cinturones orientados aproximadamente E-W de anomalías gravimétricas positivas limitan por el norte y el sur respectivamente a las anomalías antes descritas. En general los bajos gravimétricos son debidos al relleno sedimentario de la cuenca, en tanto que las anomalías residuales positivas son el producto de afloramientos del complejo basamental. El patrón de las anomalías nos permite inferir las características generales de la cuenca. Ella comprende dos sub-cuencas separadas por un alto estructural. La cuenca occidental es la más profunda y compuesta. Comprende dos sub-cuencas separadas por un alto estructural menor, posiblemente relacionado con la continuación hacia la cuenca del complejo cristalino. En general, estas sub-cuencas tienden a ser más someras hacia el oriente indicando que la cuenca evolucionó de oeste a este. Las direcciones de migración de hidrocarburos probablemente generados en el depocentro han sido indicadas. La acumulación de hidrocarburos a lo largo de estas direcciones es posible, pero estudios sísmicos y gravimétricos más detallados deben ser emprendidos para buscar trampas estructurales o estratigráficas. Este estudio puede servir de base a un programa integral de exploración petrolera.
\end{abstract}

Palabras clave: Anomalía gravimétrica, mapas residuales y regionales, relleno sedimentario, estructura de la cuenca, migración de hidrocarburos.

\begin{abstract}
Preliminary gravity results for the Mamfe Basin in the border region of northwestern Cameroon with southeastern Nigeria are reported. No geophysical studies were available for this important area, which is genetically related to oil and gas deposits in the Benue Trough. Regional and residual gravity components were obtained by least-square fitting of a third-degree polynomial surface to the Bouguer anomaly. The residual anomalies feature two NE-SW gravity lows attributed to sedimentary infill about the localities of Ekok and Agbokem, and about Mukonyong, Mamfe and Bachuo Akagbe. The gravity highs to the north and south are associated with outcrops of the basement complex. This structure corresponds to two major basins separated by a structural high. The deeper western sub-basin comprises two sub-basins separated by a minor structural high possibly related to the crystalline basement. These sub-basins tend to be shallower in the eastern direction possibly indicating the direction of migration of hydrocarbons. More detailed gravity and seismic studies may lead to discoveries of structural or stratigraphic traps. We conclude that the area is a promising prospect in terms of oil and gas prospecting.
\end{abstract}

Key words: Gravity anomaly, residual and regional maps, sedimentary infill, basin structure, hydrocarbon migration.

\section{Introduction}

The Mamfe basin is the smallest of three side rifts associated with the Benue trough of west-central Africa
(Figure 1). It is $130 \mathrm{~km}$ long by $60 \mathrm{~km}$ wide, and it extends from the lower Benue trough in Nigeria into southwestern Cameroon where it narrows and terminates under the Cameroon volcanic line. Until recently, this basin had been 


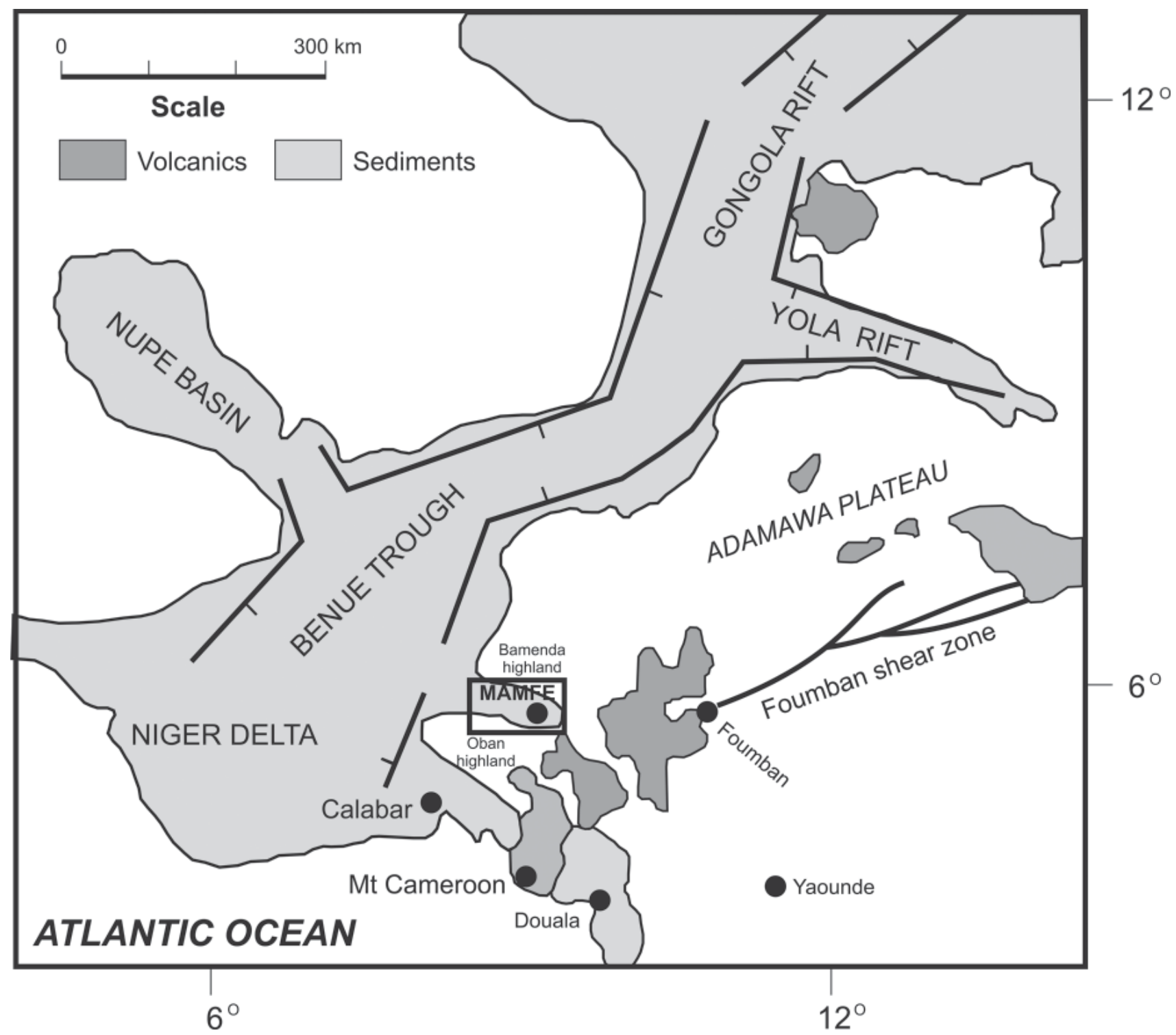

Fig. 1. Location of associated rifts in the Benue Trough. The Mamfe basin and the study area are indicated (after Fairhead et al., 1991).

devoid of geophysical studies excerpt for regional geology and crustal structure.

We provide a new interpretation of three gravity surveys with a total of 520 stations in Nigeria and Cameroon (Fairhead et al., 1991). The measurements were spaced between 1 and $3 \mathrm{~km}$ along available roads, tracks, footpaths, and river banks using a Scintrex CG-2 and a LaCoste and Romberg gravity meters. The survey was referred to base stations at Calabar, (Nigeria), and Douala, (Cameroon). A secondary base at the border post of Ekok bridge was used to tie the different surveys together. Elevations were obtained with Paulin, Thommen, and Baromec altimeters, with a nominal accuracy of $5 \mathrm{~m}$. Topographic maps at scales of 1:50,000, and 1:100,000, and a photomosaic were used to locate the stations within an accuracy of +/- 100 $\mathrm{m}$. The Bouguer anomaly was calculated for a density of $2.67 \mathrm{~g} / \mathrm{cm}^{3}$ (Figure 2). The IGSN71 international gravity formula was used together with the geodetic reference system 1967 (GRS67). The theoretical error varies from +/- 1.3 to $+/-2$ mGal.

The different regional components were identified, based on a qualitative analysis from the Bouguer anomaly (Figure 2), and a preliminary quantitative interpretation was limited to a 2-D gravity model of one profile in the Mamfe basin (Fairhead et al., 1991). Their study established the existence of a $100 \mathrm{~km}$ wide positive Bouguer anomaly 
with an amplitude in excess of $20 \mathrm{mGal}$ in the western portion of the basin. This regional anomaly has an E-W gradient. Superimposed on this regional anomaly we have a negative Bouguer anomaly associated with the sedimentary basin infill. The regional anomaly was interpreted as due to crustal thinning of about $8 \mathrm{~km}$ beneath the basin, and the residual was interpreted as due to $3 \mathrm{~km}$ thickness a basin sedimentary infill. The inferred thickness in the eastern portion of the basin was much smaller. The study did not provide more detailed information about the basin structure.

However, the gravity data may be used to provide more geophysical information on the Mamfe basin. This information turns out to be very interesting in terms of the basin evolution, and the eventual presence of hydrocarbons. Separating the gravity effects associated with shallow and local gravity sources from more regional and deeper effects, using regional-residual separation, we can obtain an improved correlation between the geology and the gravity anomalies. Residual gravity anomaly can be useful in (1) qualitative studies of the structure of the substratum and the evolution of the basin sedimentary infill (Schoeffler, 1975; Dobrin and Savit, 1988; Parasnis, 1997; Ndougsa, 2004), (2) evaluating groundwater resources in a sedimentary basin, and its oil and gas potential. In particular, a preliminary evaluation of preferred directions of lateral migration of hydrocarbons may be obtained. At this stage there is no need of geochemical data to define the characteristics of the oil and the source strata. However, gravity maps can constitute an excellent tool to help define the oil and gas paths of migration, as well as the presence of possible oil traps (i.e., Pratsch, 1986; IGC, 1995). If there is a linear regional gravity gradient, as is the case here, least-square methods can be a good approach to the regional-residual separation process.

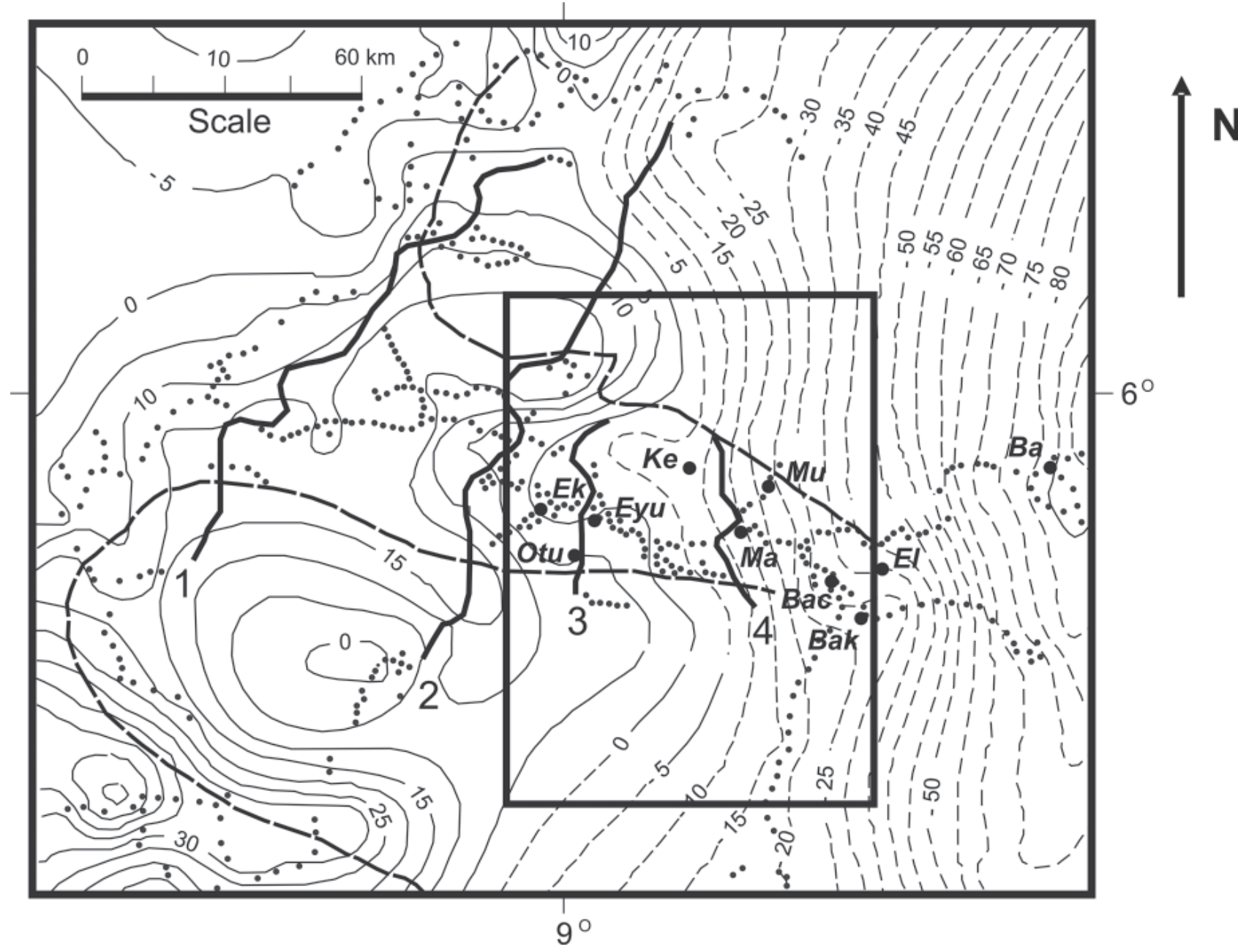

Fig. 2. Bouguer anomaly map of the Mamfe basin. Location of the study area is indicated by the rectangle (modified from Fairhead et al., 1991). Dots represent locations where gravity measurements were conducted. The thick lines represent the locations from the gravity profiles analyzed by Fairhead et al. (1991). Ek=Ekok; Eyu=Eyumojok; Ke=Kesham; Ma=Mamfe; Mu=Mukonyong; Et=Etuku; $\mathrm{Bac}=$ Bachuo Akagbe; Bak=Bakebe. 
We pursued a formal interpretation of the gravity data, focusing on the basin structure. As a first step, a regionalresidual separation based on a third degree polynomial fit to the Bouguer anomaly data in the Mamfe basin was undertaken. Based on the residual anomaly, we inferred the main features of the basin structure and we addressed, in a preliminary way, some aspects of fluid migration and probable accumulation in the Mamfe sedimentary basin situated in western Cameroon and southeastern Nigeria (Figure 1).

\section{General geology of the study area}

Figure 3 shows the available geologic map from our study area. Due to a dense and thick vegetation cover, some geologic features have been extrapolated or inferred. This geologic map is of a preliminary nature, and at present is being revised. The study area comprises the Cameroon portion of the Mamfe basin, between $5^{\circ} 30^{\prime}$ to $6^{\circ} 10^{\prime} \mathrm{N}$ and $8^{\circ} 50^{\prime}$ to $9^{\circ} 45^{\prime} \mathrm{E}$ (Kangkolo and Ojo, 1995; Kangkolo, 2002; Ndougsa et al., 2004). This area is known to contain valuable deposits of salt, sapphire and lead-zinc mineralization (Dumort, 1968; Eben, 1984; Fairhead et al., 1991; Kangkolo, 2002; Ndougsa et al., 2004; Ndougsa and Gweth, 2005).

The Mamfe basin straddles the border between southeastern Nigeria and western Cameroon (Figures 1 and 3). It extends eastwards from the lower Benue Trough. It is limited to the NE and SW by the Bameda and Oban highlands of about $500 \mathrm{~m}$ elevation, which belong to the southwestern Adamawa uplift (Figures 1 and 3). The Precambrian basement contains granites, gneisses and migmatites; it crops out at these elevations. The sedimentary infill is largely covered by dense forests; it features sandstones, mudstones, shales, limestones, mudstones, microconglomerates and polygenic conglomerates from Aptian to Albian age (Hell et al., 2000; Ndougsa et al., 2004). In the lower Benue Trough a sedimentary thickness of about $2000 \mathrm{~m}$ has been reported (Olade, 1975). The basin narrows towards the east and disappears under Tertiary and Recent rocks from the Cameroon volcanic axis containing basalts, trachytes, and rhyolites (Fitton, 1980). A Senonian deformational event affected the Benue Trough between 80 and $70 \mathrm{Ma}$, giving rise to faults and folds oriented parallel to the Benue Trough axis. Several small NW trending anticlines are reported at the eastern end of the Mamfe basin. On the Mouyana river $\left(9^{\circ} 03^{\prime} \mathrm{N}\right.$, $\left.5^{\circ} 03^{\prime} \mathrm{E}\right)$, the Cretaceous sediments dip nearly vertically close to a fault zone. Along the banks of the Cross River the sediments dip $5^{\circ}$ to $15^{\circ}$ to the southwest (Hell et al., 2000; Ndougsa et al., 2004).

\section{Gravity data and constraints for the regional-residual separation}

In the study area the Bouguer anomaly features a general E-W gravity gradient (Figure 2). The positive values at the western portion of the study area decrease eastwards. The iso-lines present an approximately N-S direction. This is clearer in the eastern half. A series of short wavelength undulations distort this pattern. These short wavelength undulations are more marked at the western portion. The undulations that distort the general E-W gradient are in fact due to residual anomalies superposed to the regional. Indeed, the analysis of the undulations present in the Bouguer anomaly map let us infer the existence of three approximately E-W belt of anomalies. Accordingly, we have a very conspicuous gravity low associated with the Mamfe basin in its western portion (comprising Eyumojok, Ekok, Otu). Eastward of Kesham the undulations are less marked, but we can also deduce the presence of another gravity low covering the eastern portion of the basin (comprising Mamfe, Bachuo Akagbe, Bakebe, and Etuku). This approximately E-W belt of gravity lows is limited to the north as well as to the south by belts of gravity highs. These gravity high are associated with the highlands of Bamenda and Oban (i.e., to the crystalline basement). Fairhead et al. (1991) had already identified two components in the regional gravity anomaly: 1) a regional gravity high upon which the gravity low associated with the basin sedimentary infill is mounted, and 2) an E-W gravity gradient causing the gravity values to decrease from 0 to $-100 \mathrm{mGals}$. Our analysis let us confirm the existence of the regional E-W gravity trend, and of the gravity low associated with the basin infill. However, we believe that 20 mGals, $150 \mathrm{~km}$ gravity high reported by Fairhead et al. (1991) is in fact an intermediate wavelength anomaly associated to the crystalline terranes limiting the basin to the north and south respectively.

In a first step of the analysis of the gravity data set, and in order to establish the basin structure, we undertook a regional-residual separation. Fairhead's et al. (1991) Bouguer anomaly map was manually interpolated to obtain a $5 \mathrm{~km}$ equispaced grid of 92 per $115 \mathrm{~km}$ (Ndougsa, 2004). Let's recall that even if the gravity station coverage from the Mamfe basin is quite good, the basement areas to the north and south of it are not well covered due to access problems. However, additional data points lying outside the study area helped to constraint the E-W regional gradient featuring the Bouguer anomaly (i.e., Fairhead et al., 1991).

This grided data set was used to conduct the regionalresidual separation based in least square fitting of polynomial surfaces. The fundamentals from the use of the least squares method in the regional-residual 


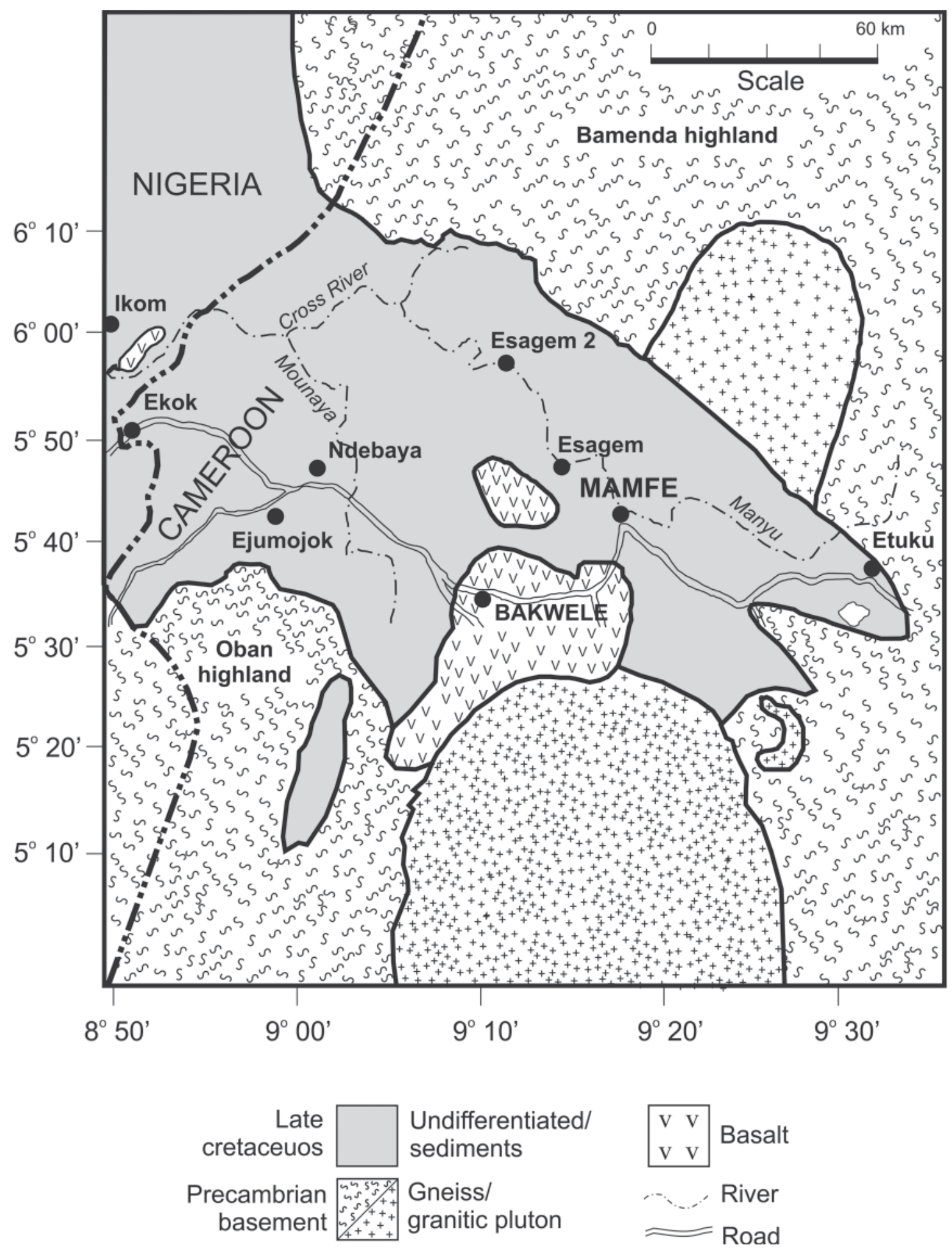

Fig. 3. Detailed geological map of the study area (modified after Fitton, 1980, and Ngando et al., 2004).

separation problem have long been well established. A thorougful description can be found elsewhere (i.e., Simpson, 1954; Schoeffler, 1975; Radhakrisna Murthy and Krishnamacharyulu, 1990; Thurstan and Brown, 1992; Parasnis, 1997; Ndougsa, 2004). We used the Radhakrishna
Murthy and Krishnamacharyulu's (1990) algorithm to adjust polynomial surfaces to the Bouguer anomaly map (Gupta and Ramani, 1980; Gupta, 1983; Gobashy, 2000; Ndougsa, 2004) to elaborate a Turbo Pascal computer program (Njandjock et al., 2003; Ndougsa, 2004). 
The corresponding residuals were controlled for the presence of unreal anomalies. A close correlation was sought between the residual anomalies and the geology, in particular the coincidence between the gravity lows and the limits from the basin. This control helped us to check if the obtained residuals were biased by the least square method. The residual anomalies corresponding to first and second degree polynomial surfaces comprised anomalies not observed in the Bouguer anomaly map (i.e., mathematical artefacts). The best fit was obtained with a third degree polynomial surface given by:

$\operatorname{Reg}(\mathrm{X}, \mathrm{Y})=4.18952+0.17817 \mathrm{X}+0.286653 \mathrm{Y}-0.00031 \mathrm{X}^{2}$ $-0.01036 X Y-0.00532 Y^{2}-0.000025 X^{3}-0.0000045 X^{2} Y$ $+0.0000444 X^{2}+0.0000344 Y^{3}$

Where $\mathrm{X}$ and $\mathrm{Y}$ are in $\mathrm{km}$ and $\operatorname{Reg}(\mathrm{X}, \mathrm{Y})$ in mGals. This polynomial, evaluated at the analyzed points, provided the regional. The residual was then obtained in a straightforward way by substracting the obtained regional from the Bouguer anomaly. The regional and residual anomalies maps were contoured using windsurfer (Golden Software, 1994) (Figures 4 and 5).

\section{Results and Discussion}

\section{Analysis of the regional anomaly map}

The obtained regional gravity anomaly map (Figure 4) reproduces most of the already described regional features observed in the Bouguer anomaly map. We have a general E-W gravity gradient. The iso-lines show an approximately $\mathrm{N}-\mathrm{S}$ orientation, except to the west where the iso-lines show undulations. The location of the $0 \mathrm{mGal}$ iso-line corresponds to the position that can be inferred from the qualitative analysis of Bouguer anomaly map. The general E-W gravity gradient increases eastwards as expected. As can be observed, the corresponding residual anomalies correlate fair well with the geology. In particular the gravity lows delimit approximately fairly well the basin, while the gravity highs correspond to areas where the basement or volcanic rocks have been mapped. As already mentioned, this fact was used to judge if a good adjustment is provided by the regional adopted.

\section{Analysis of the residual anomaly map and correlation with geology}

The residual anomalies correspond in number and in shape to those expected from the qualitative analysis of the Bouguer anomaly (see above). In the residual anomaly map (Figure 5) we observe two major gravity lows. The first one, located to the west, is of a composite nature and encompasses the towns of Ekok and Agbokem to the west and east respectively, and Otu and Eyumojok to the south. This anomaly is separated from the second major anomaly located to the east, by a relative gravity high around Kesham. The first anomaly is constituted by a larger gravity low (amounting $-9 \mathrm{mGal}$ ) at its western portion and with a mean NW-SE orientation. A second low of this first major anomaly is centred at Agbokem with a minimum of $-8 \mathrm{mGal}$. A small relative gravity high puts these two anomalies in contact. To the north and south of this relative gravity high we have two small gravity highs possible associated with basin wards continuations from metamorphic rock of the highlands. The second global gravity low is oriented NW-SE encompassing Mukonyong, Mamfe, and Bachuo Akagbe. It has a magnitude of - 5 $\mathrm{mGal}$. From its western limit to its centre it is featured by a SW-NE $1.3 \mathrm{mGal} / \mathrm{km}$ gravity gradient.

All these anomalies indicate that the Mamfe Basin has a complex structure, being constituted by three subbasins separated by structural highs (between Agbokem and Mukunyong the major one, and a minor one to the north of Eyumojok). We can infer that the thickness of the sub-basins decrease eastwards. The contour $0 \mathrm{mGal}$ coincides approximately with the basin-metamorphic rocks contact.

Besides the two minor gravity highs already mentioned, we observe two approximately E-W positive anomalies to the north and south of the negative anomalies already described. In the southern belt, in its central portion, stands out a major $+4 \mathrm{mGal}$ gravity high with a triangular shape oriented NE-SW. To the east and west we have two other non closed gravity highs. In the northern belt, an E-W elongated, $+9 \mathrm{mGal}$ high covers the western half and extends even beyond eastwards. These two belts of anomalies are associated either to outcroppings of metamorphic rocks from the highlands bordering the Mamfe basin, or to volcanic intrusions from Cameroon volcanic line. This inference facts are supported by the presence of basement outcrops and basaltic rocks at certain areas like Bakwelle and to south-east of Eyumojok (Ngando et al., 2004; Ndougsa, 2004). In this context the minor gravity high around Eyumojok would be due to a basin ward continuation of the gneiss outcropping at the Oban highland. A similar interpretation can be proposed for the second minor gravity high (i.e., that located to the north at the other side from the basin). The major anomaly from the northern high belt is inferred to be due to the metamorphic basement. We interpret the gravity lows as due to the sedimentary infill from the sub-basins, while the relative gravity highs associated to structural highs or to the presence of either metamorphic or volcanic rocks. 


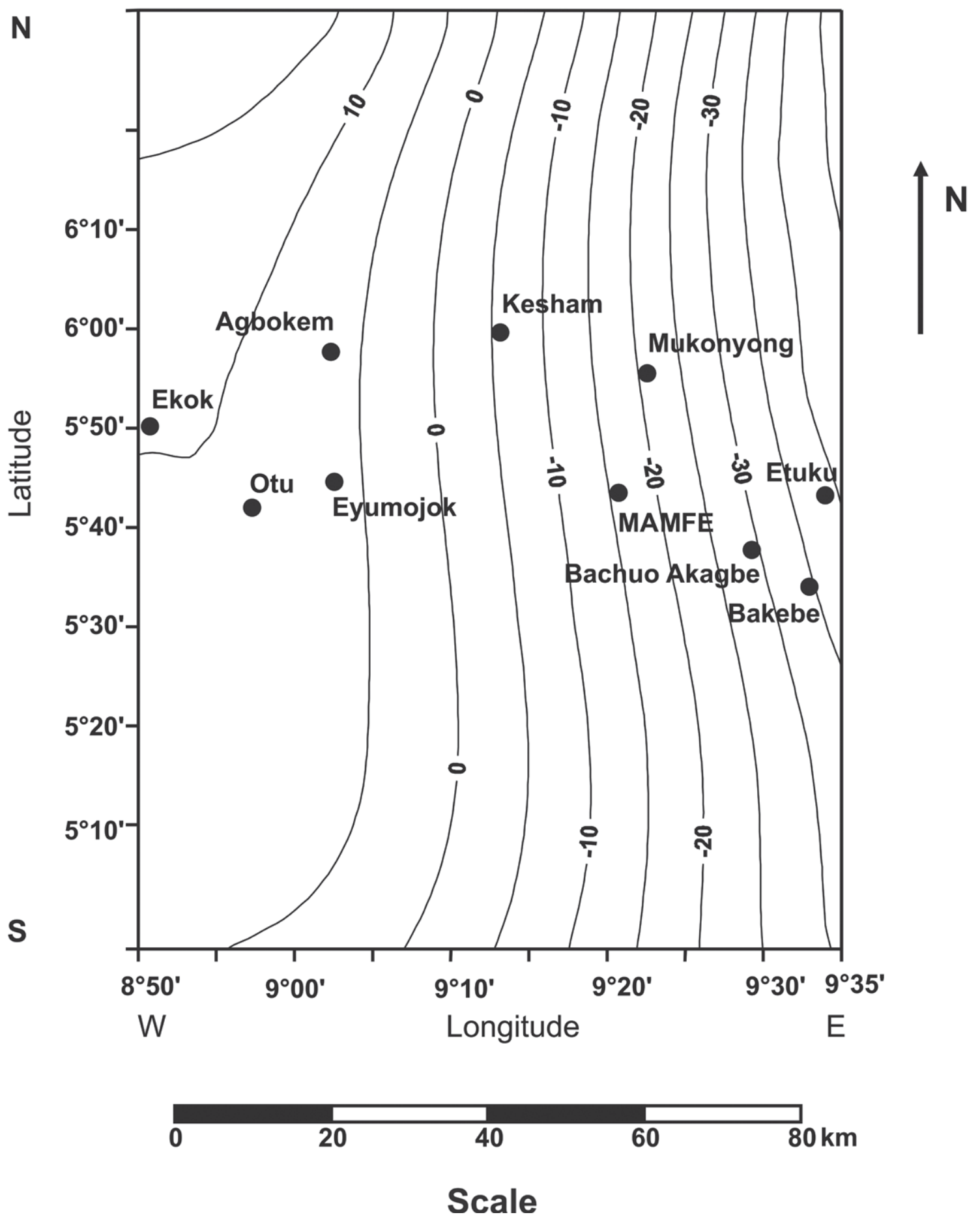

Fig. 4. Third degree regional anomaly map. Contour interval $5 \mathrm{mGal}$. -5 isogal.

However, some portions from the central gravity lows do not hold this general pattern. For example, the western gravity low extends southwards into the metamorphic terrane from the Oban highland. The eastern gravity low extends northwards into the Bamenda highlands. These conflicting facts might be accounted for by the already mentioned lack of gravity measurements outside the central Mamfe basin (see Figure 2), partially can also be associated with the problems affecting the geologic map (Figure 3). Gravity measurements must be conducted in these portions in order to solve for these contradictions. 


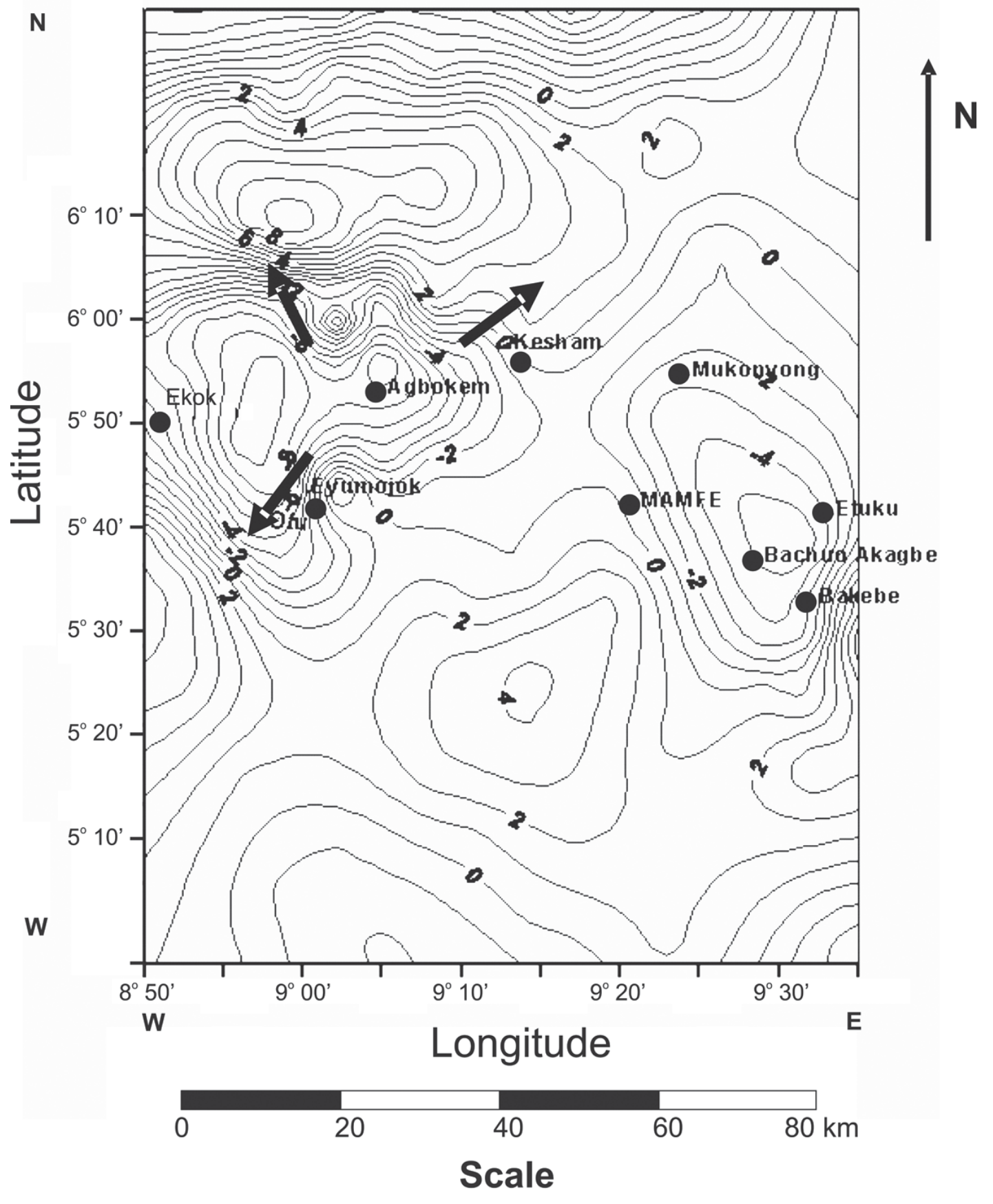

\section{Probable directions of fluid resources migration}

Fig. 5. Third degree residual anomaly map. Contour interval $1 \mathrm{mGal}$.

The residual anomaly map and probable directions of fluids migration

Generation, maturation, migration of fluids under lithostatic charge and accumulation in structural or stratigraphic traps, led to the formation of oil and gas fields. In a gravity anomaly map from a sedimentary basin, vertical migration has no or minor expression, however the lateral migration component can be defined and predicted. Indeed, regional and residual gravity maps are commonly used to 
determine the migration directions of gas and oil in a basin. Consequently, the prediction of the presence or absence of gas and oil in the traps of a specific area can thus be supported on gravity maps (Pratsch, 1986, 1994; IGC, 1995 and 2002). The subsurface pressure is a function from the sediment thickness (i.e., the sediment weight). Under the effect from the pressure, in-place generated resources fluids migrate laterally, along the carrier bed, towards the basin flanks in directions perpendicularly to the regional structure contours. For the Mamfe basin, the residual anomaly enables one to infer the general aspects of its structure. In particular, it has been established that the basin is constituted by three sub-basins. Being the western one the deepest, with its depocenter located at its southern portion. The presence of oil and gas in the basin might be due to two factors: 1) in-situ generation, and 2) migration of fluids into this sub-basin from the exterior.

According to the first factor, it seems logic to expect the existence of oil source beds in the basin, for example at the basin depocenter. This expectance is related to the existence of oil and gas in the Benue Trough. The thick sedimentary column would contribute to the pressure necessary for the fluids lateral migration from the depocenter towards the basin flanks. Most oil and gas resources migrating towards the basin flanks will accumulate in stratigraphic, structural traps, intrabasement block faulting and top basement structure. The presence of these kinds of traps, whose existence can be established from a more detailed gravity map, will constitute prospects of oil and gas concentration. The existence in the area (i.e., at the eastern end of the Mamfe basin) of small NW trending anticlines imply the existence of structural traps for these fluids. However, a detailed gravity study including additional gravity measurements must be done to delimit these structural traps. The residual gravity anomaly helps us to delinate the location from the depocenter by a gravity low closure. Figure 6 provides a simplified schematic representation from the Mamfe basin, indicating the location of its depocenter (located east of Ekok), and its step structure.

The existence of Cretaceous potential source beds in the basin is a natural expectation due to their existence elsewhere in the Benue Trough. Accordingly, the western sub-basin is significant in terms of in-situ oil and gas generation.

Because of the existence in the Benue Trough of oil and gas fields, the second factor acquires great importance. In fact, oil and gas generated in potential source-beds in the Benue Trough, could have migrated into the Mamfe basin. The oil and gas might have migrated into the

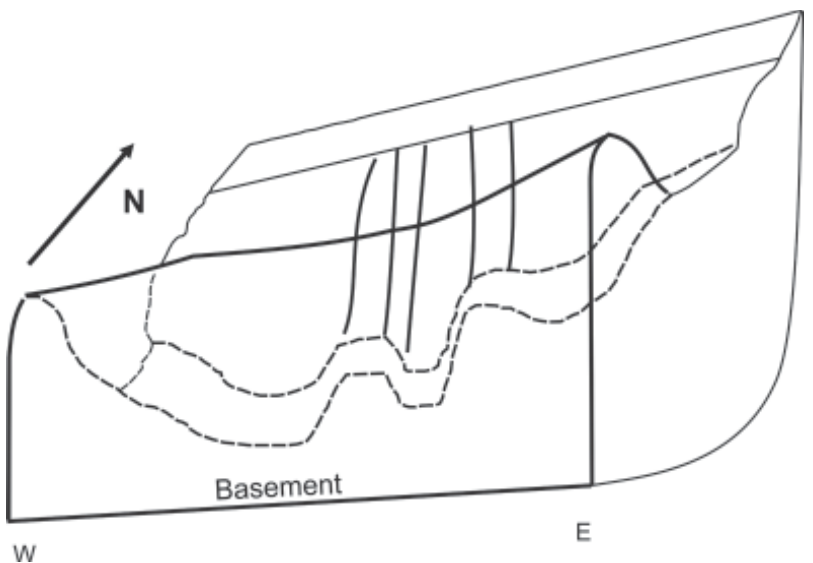

Fig. 6. E-W schematic representation from the Mamfe basin.

sedimentary formations now constituting the basin infill from the Mamfe basin at or short after the time of the hydrocarbon generation.

The structural highs limiting the basin to the north and south respectively, noticeable in the residual gravity anomaly map, can be used to indicate the possible migration paths in either of the two mentioned cases. It is possible that oil and gas migration have taken place perpendicularly to the basin contours (along the direction schematized in Figure 5 by arrows).

\section{Conclusions}

A separation of the regional and residual anomalies over the Mamfe sedimentary basin in southwestern Cameroon and southeastern Nigeria was carried out. It was based in the fitting of a third degree polynomial surface to observed Bouguer anomaly data. In particular the third degree residual gravity map has permitted to identify three subbasins with the deepest one in the western part of the basin in whose depocenter probably oil and gas accumulation/ formation have taken place. This depocenter is situated probably at the east of Ekok area. The basin is progresivaly shallower eastwards. From the third-order residual anomaly map it can be deduced that the sedimentary infill thickness decreases from the west towards the east. In general positive residual anomalies observed are the effect of outcrop of the heterogeneous basement complex while, the gravity lows are due to the basin sedimentary infill. Gravity measurements are needed to corroborate the southern and northern extensions from the western and eastern central gravity lows.

This qualitative analysis and discussion has led the authors to obtain some information on the basin, but it is not sufficient, so in further works we will carry out a 
2.5D and 3D modelling in order to realize a quantitative characterization of the thickness of the sedimentary layer and the reservoir parameters of the basin.

\section{Acknowledgments}

Comments and suggestions by two anonymous reviewers helped to improve the paper.

\section{Bibliography}

DOBRIN, M. B. and C. H. SAVIT, 1988. Introduction to Geophysical Prospecting: Eds., Mc Graw-Hill 4, Canada, Chapter 14, pp. 600-607.

DUMORT, J. C., 1968. Notice explicative sur la feuille Douala Ouest: République Fédérale du Cameroun: BRGM. 69p.

EBEN, M. M., 1984. Report of the Geological expedition in the Gulf of Mamfe: Archives of the Department of Mines \& Geology, Ministry of Mines \& Power, Cameroon, 10p.

FAIRHEAD, J. D., C. S. OKEREKE and J. M. NNANGE, 1991. Crustal Structure of the Mamfe basin, West Africa, based on gravity data. Tectonophysics, 186, 351-358.

FITTON, G., 1980. The Benue through and the Cameroon line: a migrating rift system in west Africa. Earth Planet Sci. Lett., 51, 132-138.

GOBASHY, M. M., 2000, Basin evaluation from gravity measurements using simplex algorithm with application from Sirt basin, Libya. Bulletin of Fac. Sci., Zagazig University, 22, 62-80.

GOLDEN SOFTWARE INC., 1994. Windsurfer version 5.01, Surface mapping system: 809 14th Street Golden Colorado, 80401.

GUPTA, V. K., 1983. A least squares approach to depth determination from gravity data. Geophysics, 48, 357-360.

GUPTA, V. K., and N. RAMANI, 1980. Some aspects of regional-residual separation of gravity anomalies in a Precambrian terrain. Geophysics, 45, 1412-1426.

HELL, J. V., V. NGAKO, V. BÉA, J. B. OLINGA and J. T. EYONG, 2000. Rapport des travaux sur l'étude de reconnaissance géologique du bassin sédimentaire de Mamfé: IRGM-NHC (National Hydrocarbon Corporation) unpublished report, $55 \mathrm{p}$.

INTEGRATED GEOPHYSICS CORPORATION (IGC), 1995. Bouguer gravity maps identify regional basin structure and resultant preferred directions of lateral oil and gas migration: IGC Footnotes Series on interpretation, 3(1), 1-6. Houston, Texas.

INTEGRATED GEOPHYSICS CORPORATION (IGC), 2002. Integrated stratigraphic analysis for exploration production: Sequence stratigraphy architecture as a framework for integration of modern geophysical and geological data: IGC Footnotes Series on interpretation, February, 1-4.

KANGKOLO, R., 2002. Aeromagnetic study of the Mamfe basalts of southwestern Cameroon. Journal of the Cameroon Academy of Sciences, 2(3), 173-180.

KANGKOLO, R. and S. B. OJO, 1995. Integration of aeromagnetic data over the Mamfe basin of Nigeria and Cameroon: Nigerian journal of Physics 7, 53-56.

NDOUGSA MBARGA, T. and P. NTEP GWETH, 2005. Report on the Mamfe salt and sapphire reconnaissance expedition: Internal Report Archives N0058/2005 of the Ministry of Industry, Mines and Technological Development, $12 \mathrm{pp}$.

NDOUGSA MBARGA, T., E. MANGUELLE-DICOUM, D. BISSO and N. NJINGTI, 2004. Geophysical evaluation based on gravity data of the Mamfe basin, Southwest Cameroon: SEGMITE International. A Journal of Resource, Industrial and Environmental Geology, 1(1), 15-20.

NDOUGSA MBARGA, T., 2004. Etude géophysique par méthode gravimétrique des structures profondes et superficielles de la region de Mamfé: Thèse Doctorat/ PhD, Fac., Sci., Univ., Youndé I, 255 p.

NGANDO, A. M., C. T. TABOD, E. MANGUELLEDICOUM, R. NOUAYOU, J. MARCEL and A. ZAKARIAOU, 2004. Structure géologique le long de deux profils audio magnétotelluriques dans le bassin de Mamfé. Journal of Cameroon Academy of Science, 4(2), 149-162.

NJANDJOCK, N. P., H. L. KANDÉ, E. MANGUELLEDICOUM, C. T. TABOD, J. MARCEL and T. NDOUGSA MBARGA, 2003. A Turbo Pascal 7.0 
program to fit a polynomial of any order to potential field anomalies based on the analytic least squares method. African Journal of Sciences and Technology, Sciences and Engineering series, 4 (2), 1-4.

OLADE, M. A., 1975. Evolution of Nigeria's Benue Trough (Aulacogen): A tectonic model: Geological magazine, 112(6), 93-103.

PRATSCH, J. C., 1986. The distribution of major oil and gas reserves in regional basin structures an example from the Powder River basin, Wyoming, USA. Journal of Petroleum Geology, 9(4), 393-412.

PRATSCH, J. C., 1994. The location of major oil and gas fields: examples from the Andean Foreland. Journal of Petroleum Geology, 17(3), 327-338.

PARASNIS, D. S., 1997. Principles of Applied Geophysics: 5th edition Chapman and Hall, London, England, 400 p.

RADHAKRISHNA MURTHY, I. V. and S. K. G. KRISHNAMACHARYULU, 1990. A Fortran 77 Program to fit a polynomial of any order to Potential Field Anomalies. Jour. Assoc. Expl. Geophys. 11 (2), 99-105.

SCHOEFFLER, J., 1975. Gravimétrie appliquée aux recherches structurales et à la prospection pétrolière et minière: Eds. Technip, Paris, France, 288 p.
SIMPSON, S. M., 1954. Least-squares polynomial fitting to gravitational data and density plotting by digital computer. Geophysics, 19, 808-811.

TELFORD, W. M., L. P. GELDART, R. E. SHERIFF and D. A. KEYS, 1990. Applied geophysics: 2th edition, Cambridge University press, Cambridge, G.B., 770 p.

THURSTON, J. B. and R. J. BROWN, 1992. The filtering characteristics of least-squares polynomial approximation for regional/residual separation. Can. Journal of Expl. Geophy, 28(2), 71-80.

Théophile Ndougsa-Mbarga ${ }^{1 *}$, Eliezer ManguelleDicoum $^{2}$, José-Oscar Campos-Enriquez ${ }^{3}$ and Quentin Yene Atangana $^{4}$

${ }^{1}$ Department of Physics, Advanced Teachers' Training College, University of Yaounde I, P. O. Box 47 Yaounde, Cameroon. Personal address: P.O. Box 12529 Yaounde, Cameroon.

${ }^{2}$ Department of Physics, Faculty of Science, University of Yaounde I, P. O. Box 812 Yaounde, Cameroon.

${ }^{3}$ Instituto de Geofísica, Universidad Nacional Autónoma de México, Del. Coyoacán, 04510 Mexico City, México.

Email:ocampos@geofisica.unam.mx

${ }^{4}$ Department of Earth Science, Faculty of Science, University of Yaounde I, P. O. Box 812 Yaounde, Cameroon.

*corresponding author: Email: tndougsa@yahoo.fr 